\title{
Suitability of three red macroalgae as a feed for the abalone Haliotis tuberculata coccinea Reeve
}

\author{
M.P. Viera ${ }^{\mathrm{a}, *}$, J.L. Gómez Pinchetti ${ }^{\mathrm{b}}$, G. Courtois de Vicose ${ }^{\mathrm{a}}$, A. Bilbao ${ }^{\mathrm{a}}$, S. Suárez ${ }^{\mathrm{b}}$, \\ R.J. Haroun ${ }^{\mathrm{a}}$, M.S. Izquierdo ${ }^{\mathrm{a}}$ \\ ${ }^{\mathrm{a}}$ Grupo de Investigación en Acuicultura (GIA), ULPGC and ICCM, P.O. Box 56. 35200, Telde, Las Palmas, \\ Gran Canaria, Canary Islands, Spain \\ ${ }^{\mathrm{b}}$ Grupo de Algología Aplicada. Centro de Biotecnología Marina, Universidad de Las Palmas de Gran Canaria. Muelle de Taliarte s/n, \\ 35214 Telde, Las Palmas. Canary Islands, Spain
}

Received 27 July 2004; received in revised form 17 February 2005; accepted 1 March 2005

\begin{abstract}
A 60-day feeding trial was conducted to assess the suitability of three red algae, Hynea spinella, Hynea musciformis and Gracilaria cornea, as potential feed for the culture of juvenile abalone, Haliotis tuberculata coccinea $\mathrm{R}$. Seaweeds were reared in a biofiltration unit with fishpond waste water effluents. The three algal species were found to contain high protein contents which would be related to its production under the high nitrogen culture conditions of the biofilter system. Protein and carbohydrate contents were highest in H. musciformis and lowest in G. cornea. Survival rates of juvenile abalone were very good, regardless of the algae fed. Feed intake of $H$. spinella was highest, followed by $H$. musciformis. Growth rates of abalone were within the range obtained under commercial conditions, final shell length and weight being significantly highest in animals fed H. spinella and lowest in those fed G. cornea. Feeding G. cornea lead to the lowest growth performance due to the lowest feed intake, whereas feed conversion ratios were significantly highest for $H$. musciformis and protein efficiency ratios were higher for both H. spinella and G. cornea. This study suggested the good potential of any of the three red seaweeds testedsuccessfully produced by the biofilter system, their nutritional composition being similar to other macroalgae used as feed for abalone and matching the abalone protein and lipid requirements - hence promoting growth and survival. Nevertheless, the biofilter produced macroalgae $H$. spinella showed the highest dietary value for juvenile of $H$. tuberculata coccinea .
\end{abstract}

(c) 2005 Elsevier B.V. All rights reserved.

Keywords: Haliotis tuberculata coccinea; Macroalgae; Seaweed biofilter; Polyculture; Feeding and nutrition—molluscs

* Corresponding author. Tel.: +34 928 132900/04; fax: +34 928 132908 .

E-mail address: mapi@iccm.rcanaria.es (M.P. Viera).

\section{Introduction}

Commercial aquaculture in the Canary Islands is limited to the production of marine fish species such as gilthead seabream and European sea bass, with 
species diversification being a challenge for further local aquaculture development. The potential as a new species for aquaculture of the Canarian abalone Haliotis tuberculata coccinea R., whose natural population is becoming depleted due to overfishing, relies on the high demand for abalone both in local and external markets, as well as on the high degree of development achieved in some other species of the family Haliotidae (Haliotis discus hannai, Haliotis asinina, Haliotis rufescens, etc.), in particular of the European ormer Haliotis tuberculata tuberculata L., with close biological characteristics. Besides, there is public interest in developing the culture techniques of this species to contribute to the recovery of wild populations. Studies on $H$. tuberculata coccinea are scarce and have been focused only on spawning (Peña, 1985, 1986; Viera et al., 2003), ecology (Pérez and Moreno, 1991; Espino and Herrera, 2002) and culture techniques (Toledo et al., 2000).

Food preferences differ among abalone species around the world, depending on habitat and food availability (Barkai and Griffiths, 1986; Dunstan et al., 1996). In the wild, abalone consumes different macroalgae species, obtaining their required nutrients from a combination of algal species. Although $H$. tuberculata coccinea feeds on a diverse assemblage of macroalgae (Espino and Herrera, 2002), its nutritional needs and the relative importance of these algae are unknown. Algal diets have been extensively used for the production of abalone (Clarke, 1988). This herbivorous gastropod can consume seaweed at a rate close to $35 \%$ of its body weight per day. Hence sustaining of growth requires a large amount of fresh macroalgae (Tahil and Juinio-Menez, 1999). Since wild algae are not commercially valuable in the Canary Islands, and hence not harvested, availability of this natural resource is scarce and insufficient to sustain the commercial production of abalone, which would require the replacement of wild seaweed as a main diet component.

In an aquaculture integrated system, nitrogenous enriched waste water of intensively cultured organisms such as fish, shrimp, and abalone may be transformed into a valuable algal biomass, seaweeds production being an added income as feed for shellfish (Evans and Langdon, 2000; Schuenhoff et al., 2003; Neori et al., 2004). Besides, several studies have shown that culture of Ulva spp. in nutrient-rich waters increases its protein content from $11 \%$ to over $32 \%$ in dry weight (Shpigel et al., 1999; Boarder and Shpigel, 2001). Thus, this biofilter produced Ulva has been shown to provide good growth rates for $H$. tuberculata (Neori et al., 1998; Shpigel et al., 1999), H. discus hannai (Corazani and Illanes, 1998; Shpigel et al., 1999) and H. roei (Boarder and Shpigel, 2001). Previous experiences in our laboratory have also shown the potential of using enriched Ulva rigida as a suitable feed for $H$. tuberculata coccinea (Viera and co-workers, unpublished data). But in the wild, Canarian abalone seem to have a higher preference for red algae (Espino and Herrera, 2002) as it has also been shown for several abalone species such as $H$. iris and H. australis (Poore, 1972; Shepherd, 1973; Wells and Keesing, 1989; Shepherd and Steinberg, 1992; Fleming, 1995), H. tuberculata or H. discus hannai (Mai et al., 1995a). Hence, in order to diversify the offer of macroalgae to cultured abalone in the Canary Islands, this study focused the evaluation of the suitability of three local red macroalgae cultivated in a biofiltration unit as a potential feed for the Canarian abalone $H$. tuberculata coccinea.

\section{Materials and methods}

\subsection{Algal culture}

Gracilaria cornea J. Agardh, Hypnea spinella (C. Agardh) Kützing and Hypnea musciformis (Wulfen) J. V. Lamoroux were grown in a flow-through integrated system consisting of two intensive fishponds stocked with gilthead sea bream and a macroalgal biofilter. Effluents were channelled from the fishponds to a 11 $\mathrm{m}^{3}$ sedimentation pond for the removal of suspended particles and, then, pumped at a flow rate of $10 \mathrm{~m}^{3}$ $\mathrm{h}^{-1}$ to the seaweed tanks located in a greenhouse, where maximum irradiance was close to $1600 \mu \mathrm{mol}$ photons $\mathrm{m}^{-2} \mathrm{~s}^{-1}$. Semi-circular fiberglass tanks with a surface of $1.8 \mathrm{~m}^{2}$, volume of $0.75 \mathrm{~m}^{3}$ and aeration supplied by a bottom-central linear pipeline were used for the cultivation of macroalgae. Algal stocking densities were adjusted to the optimal values obtained from previous experiments $\left(6 \mathrm{~g}^{-1}\right)$. Water exchange rate in the seaweed tanks was 4 vol day ${ }^{-1}$ and TAN (total ammonia nitrogen) inflow into the biofilter ranged between 10 and $400 \mu \mathrm{M}$. 


\subsection{Abalone and rearing conditions}

Abalones (H. tubercalata coccinea) were produced within the experimental hatchery production unit of the Instituto Canario de Ciencias Marinas, (Canary Islands, Spain). A total of 360 juvenile abalones (40/ replicate) with an average shell length and weight of $11.18 \pm 1.27 \mathrm{~mm}$ and $0.17 \pm 0.06 \mathrm{~g}$, respectively, were selected for the trial.

Animals were initially fed a diet of Navicula $s p$. and Nitzschia $s p$. for 4-5 months. Feeding of all abalone was then switched to the green macroalgae $U$. rigida cultured at the laboratory biofiltration system for a period of 1 month prior to the beginning of the experiment.

Individuals were blot dried, weighed to the nearest $0.1 \mathrm{mg}$ (total wet body weight: TWBW), measured with manual caliper with $0.1 \mathrm{~mm}$ accuracy (total shell length: SL) and assigned to an experimental unit. Abalones were distributed among replicates so that there were no significant differences in SL or TWBW. Each algal type was fed for 8 weeks to the experimental abalone and tested in triplicates $(9$ experimental units plus 3 control units). The experimental unit consisting of a 11 lidded (plastic net of $2 \mathrm{~mm}$ mesh) PVC plastic container $(20 \times 14 \mathrm{~cm})$, located in a $100-1$ cylindrical tank filled with $50 \mu \mathrm{m}$ filtered seawater, was provided with constant aeration. Water flowed in at approximately $2.4 \mathrm{l} / \mathrm{min}$. Water temperature ranged between 23.9 and $25.4{ }^{\circ} \mathrm{C}$. Abalones were subjected to a natural photoperiod of approximately $12 \mathrm{~h} \mathrm{~L} / 12 \mathrm{~h} \mathrm{D}$.

\subsection{Growth and algal consumption}

SL and TWBW of each animal were measured every four weeks.

Three experimental units that contained algae but no abalone were used as controls for changes in algal weight. Feed was changed once a week during the growth trial and supplied in excess to guarantee ad libitum feeding along the whole experiment. To determine feed intake, freshly collected algae to be fed to the abalone were blotted dry and accurately weighed as well as the remaining algae at the end of the week. The weight of unconsumed food was deducted from the total weekly ration. Besides, weight of uneaten algae was corrected by calculating the natural change in weight of the algae in the control units during the same feeding period.

The average daily intakes by individual abalones during the entire feeding trial were calculated by dividing the algal biomass eaten each week by the feeding days and the number of abalones in each experimental unit.

The following nutritional indices were calculated for all treatments at the end of the trial:

Shell growth rate $=\left(L_{2}-L_{1}\right) /$ days of culture $\times 1000$ Specific growth rate, $\mathrm{SGR}=\left(\operatorname{Ln} W_{2}-\operatorname{Ln} W_{1}\right) /$ $t \times 100$

Weight gain $(\%)=\left(\left(W_{2}-W_{1}\right) / W_{1}\right) \times 100$

Food conversion ratio $=$ total feed intake $(\mathrm{g}$ wet $) /$ total weight gain (g wet)

Protein efficiency ratio=(increase in body wet weight $(\mathrm{g})) /($ protein intake $(\mathrm{g}))$

where $L_{1}$ is the initial mean length of animals, $L_{2}$ is the final mean length of animals, Ln $W_{2}$ is the natural logarithm of weight at time $t$ (days of culture), and Ln $W_{1}$ is the natural logarithm of the initial weight.

\subsection{Nutritional analysis}

Homogenized samples of each type of algae provided to the abalones were analyzed in triplicate for nutrient composition. The samples collected were cleaned, washed with freshwater to remove salts and epizoos, frozen in $-80{ }^{\circ} \mathrm{C}$ freezer, freeze-dried and finely ground using an electric fine mill (sieve size $<0.1 \mathrm{~mm}$ ). The dry matter was determined by drying at $110{ }^{\circ} \mathrm{C}$ for $24 \mathrm{~h}$. Ash content was determined by incinerating samples at $600{ }^{\circ} \mathrm{C}$ for $24 \mathrm{~h}$. Protein content was analyzed according to AOAC (1995) standard methods. Total lipids were extracted with chloroform-methanol $(2: 1)$ mixture as described by Folch et al. (1957).

\subsection{Statistical analysis}

Statistical analysis was conducted using one-way ANOVA and Tukey test for multiple comparison of means with 5\% significance level was applied $(P<0.05)$. When data did not have normal distribu- 
Table 1

Proximate composition and caloric content of the three red macroalgae (g/100 g DW) (mean \pm S.D.) fed to abalone along the experimental trial

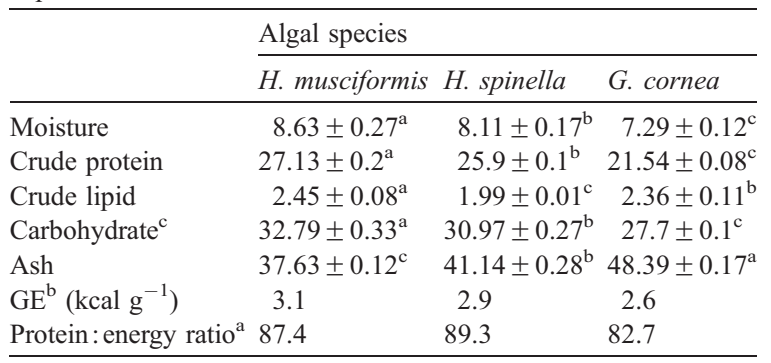

Values in the same row with different letters are significantly different $(P<0.05) n=3$.

${ }^{\text {a }}$ Metabolizable energy was calculated based on the physiological values at $5.6 \mathrm{kcal} \mathrm{g}^{-1}$ protein, $9.5 \mathrm{kcal} \mathrm{g}^{-1}$ lipid and $4.1 \mathrm{kcal} \mathrm{g}^{-1}$ carbohydrates (Cho et al., 1982).

${ }^{\mathrm{b}}$ Gross energy.

${ }^{c}$ Calculated by difference (AOAC, 1995).

tion, a non-parametric one-way ANOVA on ranks of Kruskal-Wallis was tested (Zar, 1984).

\section{Results}

\subsection{Algal nutritional composition}

Nutritional composition and caloric content of the three red seaweeds are shown in Table 1. Protein energy ratios and gross energy were very similar among the different algae. However, there were significant differences $(P<0.05)$ among the proximate compositions of the algae fed. Protein content was significantly highest in $H$. musciformis, whereas G. cornea showed the lowest. Similarly, H. musciformis showed the highest carbohydrate content and $G$. cornea the lowest. The three algal species were low in lipid content, the highest being also found in $H$. musciformis and the lowest in $H$. spinella. The ash content varied inversely to protein and carbohydrate contents and was highest in G. cornea and lowest in H. musciformis.

\subsection{Growth and consumption}

Survival, growth performance and feed utilization of juvenile $H$. tuberculata coccinea fed the macroalgae $H$. musciformis, $H$. spinella and G. cornea are shown in Table 2. Survival rates were very good and no significant differences were found among the different feeding regimes. Daily feed intake on different algal rations recorded for 8 weeks showed that all three macroalgae were very well accepted by the abalone, but a significantly higher feed intake of $H$. spinella, followed by $H$. musciformis, was registered. Hence, final shell length and weight were significantly highest in animals fed $H$. spinella and lowest in those fed with G. cornea. Accordingly, shell growth rate, specific growth rate and weight gain followed the same pattern, all these parameters being significantly highest in animals fed $H$. spinella and lowest in those fed G. cornea. Study of the feed

Table 2

Growth, feed utilization and survival of juvenile Canarian abalone (H. tuberculata coccinea) at the beginning of the experiment and after being fed the selected macroalgae for 60 days under laboratory conditions

\begin{tabular}{|c|c|c|c|}
\hline & \multicolumn{3}{|c|}{ Algae species fed to abalone } \\
\hline & H. musciformis & H. spinella & G. cornea \\
\hline Initial length (mm) & $11.18 \pm 1.27$ & $11.2 \pm 1.29$ & $11.17 \pm 1.27$ \\
\hline Final length (mm) & $15.92 \pm 1.52^{\mathrm{b}}$ & $18.54 \pm 1.73^{\mathrm{c}}$ & $14.75 \pm 1.75^{\mathrm{a}}$ \\
\hline Shell growth rate $\left(\mu \mathrm{m}\right.$ day $\left.^{-1}\right)$ & $81.79 \pm 3.23^{\mathrm{b}}$ & $126.61 \pm 5.92^{\mathrm{c}}$ & $61.71 \pm 1.73^{\mathrm{a}}$ \\
\hline SGR $\left(\%\right.$ day $\left.^{-1}\right)$ & $1.89 \pm 0.03^{\mathrm{b}}$ & $2.66 \pm 0.11^{\mathrm{c}}$ & $1.47 \pm 0.05^{\mathrm{a}}$ \\
\hline Initial weight (g) & $0.17 \pm 0.06$ & $0.17 \pm 0.06$ & $0.16 \pm 0.06$ \\
\hline Final weight $(\mathrm{g})$ & $0.51 \pm 0.15^{\mathrm{b}}$ & $0.78 \pm 0.21^{\mathrm{c}}$ & $0.38 \pm 0.12^{\mathrm{a}}$ \\
\hline Weight gain $(\%)$ & $178.41 \pm 8.63^{\mathrm{b}}$ & $348.65 \pm 30.35^{\mathrm{c}}$ & $123.64 \pm 4.43^{\mathrm{a}}$ \\
\hline Feed intake (mg abalone ${ }^{-1}$ day $^{-1}$ ) & $165.54 \pm 4.96^{\mathrm{b}}$ & $215.63 \pm 0.61^{\mathrm{c}}$ & $78.98 \pm 1.79^{\mathrm{a}}$ \\
\hline FCR & $30.49 \pm 1.64^{\mathrm{b}}$ & $20.94 \pm 1.49^{\mathrm{a}}$ & $22.09 \pm 1.15^{\mathrm{a}}$ \\
\hline PER & $1.1 \pm 0.06^{\mathrm{a}}$ & $1.68 \pm 0.1^{\mathrm{b}}$ & $1.75 \pm 0.09^{b}$ \\
\hline Survival (\%) & $93.33 \pm 2.89$ & $95.83 \pm 1.44$ & $95.75 \pm 5.1$ \\
\hline
\end{tabular}

Values in the same row with different letters are significantly different $(P<0.05) n=40 \times 3$. 
efficacy of feed utilization showed that feed conversion ratios were significantly higher for $H$. musciformis, whereas protein efficiency ratios were higher for both $H$. spinella and $G$. cornea.

\section{Discussion}

The nutritional value of food rations depends on many factors including nutrient composition, bioavailability, palability and digestibility (Serviere-Zaragoza et al., 2001). This study examined the nutritional value of three algal diets for juvenile abalone, $H$. tuberculata coccinea, by measuring biochemical composition and energy content of the algae and relating this to growth performance and feed intake of the animals.

The proximate composition of the algae was in the range of values reported for other species of seaweeds used as feed for abalone (Jackson et al., 2001; Mcbride et al., 2001). Protein content (22-27\% DW) of the three algae was within the range for red seaweeds (10-47\%) (Fleurence, 1999; Wong and Cheung, 2000) and was higher than the level found in the red seaweed, Palmaria palmata (18.4\%), which has been found to be a good algal diet for $H$. tuberculata (Mercer et al., 1993; Mai et al., 1995a). Furthermore, protein content of $H$. spinella and $H$. musciformis was higher than that reported for other species of Hypnea (4.2-19\% DW) (Portugal et al., 1983; Wong and Cheung, 2000). These high levels of protein content observed in the algae of the present study would be related to its production under the high nitrogen culture conditions of the biofilter system, as it has been also observed in Ulva spp. cultured as macroalgal biofilters (Tenore, 1976; Neori, 1996; Shpigel et al., 1996a,b, 1999). Hence, protein content of the three macroalgae used in the present experiment would match the protein requirements described for several species of Haliotis such as $H$. discus $(20 \%)$ (Ogino and Kato, 1964), H. discus hannai (20-30\%) (Uki et al., 1986a), H. kamtschatkana (30\%) (Taylor, 1992) or for H. tuberculata and H. discus hannai (25-35\%) (Mai et al., 1995b), although it would be lower than that required for $H$. midae (47\%) (Britz, 1996).

All the algae were low in lipid $(2-2.4 \%$ DW) but within the range of other species of red seaweeds
(1-3\% DW) reported previously (Mabeau and Fleurence, 1993; Wong and Cheung, 2000). Nevertheless, abalone species show low lipid requirement, typical of herbivore molluscs and fish (Mai et al., 1995a). This low lipid requirement has been associated by some authors (Durazo-Beltrán et al., 2004) with the low use of dietary lipids as energy source by abalone based upon its low metabolic rate. Indeed, high levels of dietary lipid seem to negatively affect abalone growth (Thongrod et al., 2003). However, high levels of carbohydrate enhance growth (Thongrod et al., 2003) of abalone which has various enzymes capable of hydrolysing complex carbohydrates (Fleming et al., 1996) and a good capacity to synthesize non-essential lipids from carbohydrates. In the present study, carbohydrate values (28-33\% DW) were high and comparable to those obtained for other algal species (Kaehler and Kennish, 1996; Foster and Hodgson, 1998).

Ash content of the Hypnea species was higher than that of other species of the same genus $H$. charoide (23-35\% DW), $H$. pannosa (15\% DW), and $H$. japonica (19\% DW) (Portugal et al., 1983; Wong and Cheung, 2000). High ash content in algae results from the calcium carbonate, which limit the other nutrients' presence and reduce nutrient digestibility (Horn, 1989; Hay et al., 1994).

It is generally accepted that balanced levels of protein (>15\%), lipid (3-5\%) and carbohydrate (20$30 \%$ ), with no toxic substances in natural algae, are essential for optimal growth performance of abalone (Mercer et al., 1993). From this point of view, the three algae tested appear to be able to match the abalone requirements.

Growth rates of abalone fed the dietary treatments in this study were within the range of $62-127 \mu \mathrm{m}$ day $^{-1}$, close to those obtained by other authors in similar species (50-100 $\mu \mathrm{m}$ day $^{-1}$; Viana et al., 1996, 2000; Guzmán and Viana, 1998; Gómez-Montes et al., 2003) under similar experimental conditions and to that obtained under commercial conditions $(80 \mu \mathrm{m}$ day $^{-1}$; Gómez-Montes et al., 2003). SGR values were also high $(1.5-2.7 \%)$ in comparison with those reported by Mai et al. (1996), who studied the effect of five species of macroalgae (P. palmata, Alaria esculenta, Ulva lactuca, Laminaria digitata and Laminaria saccharina) and reported SGR values of 
$1.03-1.31 \%$ for $H$. tuberculata and $0.7-1.25 \%$ for H. discus hannai.

Gracilaria species have been reported to promote high growth and survival in other species of abalone such as H. asinina (Upatham et al., 1998; BautistaTeruel and Millamena, 1999; Capinpin et al., 1999; Reyes and Fermin, 2003). In the present study feeding G. cornea lead to the lowest growth performance due to the lowest feed intake registered, since feed utilization in terms of FCR and PER was as good as those of the highest growing abalone fed H. spinella. Indeed, consumption rate in abalone may be influenced by factors other than the nutritional quality of food, such as its toughness or presence of antinutritional chemicals (Fleming, 1995). Hence, the harder texture and ash content of $G$. cornea may have affected its consumption by $H$. tuberculata since, in the wild, abalone prefer soft texture macroalgae (Shepherd and Steinberg, 1992). This preference seem to be related to the little capacity of the rhipidoglossan radula to penetrate the algal surface (Steneck and Watling, 1982) as its teeth have limited ability to exert force against the substrate.

The high FCR of the three treatments agrees well with those reported for $H$. discus hannai and $H$. tuberculata using seaweeds as food (Shpigel et al., 1999) and H. asinina fed G. fisheri (Kunavongdate et al., 1995). The higher food conversion rate (FCR) attained for abalone fed $H$. musciformis in the present study does not seem to be explained by the general composition of the algae, or by the protein:energy ratio but to a significantly lower protein efficiency ratio (PER) than the rest of the treatments, suggesting that differences in response could be attributed to differential amino acid composition. Optimum growth is achieved through proper balance of dietary nutrients and fulfillment of requirements of essential nutrients and energy (Smith, 1989; Gómez-Montes et al., 2003).

In conclusion, this study suggested the good potential of using any of the three red seaweeds tested - successfully produced by the biofilter system, their nutritional composition being similar to other macroalgae used as feed for abalone and being able to match the protein and lipid requirements of abalonehence promoting good growth and survival. Nevertheless, based on growth performance, food conversion ratio, protein efficiency ratio and protein : energy ratio, the macroalgae $H$. spinella produced by the biofilter showed the highest dietary value for juvenile of $H$. tuberculata coccinea.

\section{Acknowledgements}

The authors would like to thank to Drs. S. Thongrod, L. Robaina and D. Montero for their valuable comments on the manuscript. This study has been financed by the Spanish Government in the frame of the National Plan for Development of Marine Cultures (JACUMAR, TR 2003/08).

\section{References}

AOAC, 1995. Official Methods of Analysis of the Association of Analytical Chemistry, 15th ed. (Washington, DC, 1018 pp.).

Barkai, R., Griffiths, C.L., 1986. Diet of South African abalone Haliotis midae. S. Afr. J. Mar. Sci., 4, 37-44.

Bautista-Teruel, M.N., Millamena, O.M., 1999. Diet development and evaluation for juvenile abalone, Haliotis asinina: protein/ energy levels. Aquaculture, 178, 117-126.

Boarder, S.J., Shpigel, M., 2001. Comparative performances of juvenile Haliotis roei fed on enriched Ulva rigida and various artificial diets. J. Shellfish Res., 20 (2), 653-657.

Britz, P.J., 1996. Effect of dietary protein on growth performance of South African abalone, Haliotis midae, fed fishmeal-based semipurified diets. Aquaculture, 140, 55-61.

Capinpin, E.C.J., Toledo, J.D., Encena, V.C.I., Doi, M., 1999. Density dependent growth of the tropical abalone Haliotis asinina in cage culture. Aquaculture, 171, 227-235.

Cho, C.Y., Slinger, S.J., Bayley, H.S., 1982. Bioenergetics of salmonid fishes: energy intake, expenditure and productivity. Comp. Biochem. Physiol., 73B, 25-41.

Clarke, S.M., 1988. Abalone mariculture: the significance of algae. Austasia Aquac., 3, 9-11.

Corazani, D., Illanes, J.E., 1998. Growth of juvenile abalone, Haliotis discus hannai Ino 1953 and Haliotis rufescens Swainson 1822, fed with different diets. J. Shellfish Res., 17 (3), 663-666.

Dunstan, G.A., Baillie, H.J., Barret, S.M., Volkman, J.K., 1996. Effect of diet on the lipid composition of wild and cultured abalone. Aquaculture, 140, 115-127.

Durazo-Beltrán, E., Viana, M.T., D'Abramo, L.R., Toro-Vázquez, J.F., 2004. Effects of starvation and dietary lipid on the lipid and fatty acid composition of muscle tissue of juvenile green abalone (Haliotis fulgens). Aquaculture, 238, 329-341.

Espino, F., Herrera, R., 2002. Seguimiento de Poblaciones de Especies Amenazadas 2002 (Haliotis tuberculata coccinea, Nordsieck, 1975) Gran Canaria. Informe Final Presentado por Gesplan y la Consejería de Política Territorial y Medio Ambiente (Viceconsejería de Medio Ambiente de Gran Canaria 
y Dirección General de Política Ambiental) Informe no publicado. $52 \mathrm{pp}$.

Evans, F., Langdon, C.J., 2000. Co-culture of dulse Palmaria mollis and red abalone Haliotis rufescens under limited flow conditions. Aquaculture, 185, 137-158.

Fleming, A.E., 1995. Growth, intake, feed conversion efficiency and chemosensory preference of the Australian abalone, Haliotis rubra. Aquaculture, 132, 297-311.

Fleming, A.E., Barneveld, R.J., Hone, P.W., 1996. The development of artificial diet for abalone. Aquaculture, 140, 5-53.

Fleurence, J., 1999. Seaweed proteins: biochemical, nutritional aspects and potential uses. Trends Food Sci. Technol., 10, $25-28$.

Folch, J., Lees, M., Sloane-Stanley, G.H., 1957. A simple method for the isolation and purification of total lipids from animal tissue. J. Biol. Chem., 226, 479-509.

Foster, G.G., Hodgson, A.N., 1998. Consumption and apparent dry matter digestibility of six intertidal macroalgae by 11 (Mollusca: Vetgastropoda: Turbinidae). Aquaculture, 167, 211-227.

Gómez-Montes, L., García-Esquivel, Z., D' Abramo, L.R., Shimada, A., Vásquez-Peláez, C., Viana, M.T., 2003. Effect of dietary protein: energy ratio on intake, growth and metabolism of juvenile green abalone Haliotis fulgens. Aquaculture, 220, $769-780$.

Guzmán, J.M., Viana, M.T., 1998. Growth of abalone Haliotis fulgens fed diets with and without fish meal compared to a commercial diet. Aquaculture, 165, 321-331.

Hay, M.E., Kappel, Q.E., Fenical, W., 1994. Synergism in plant defenses against herbivores: interactions of chemistry, calcification and plant quality. Ecology, 75, 1714-1726.

Horn, M.N., 1989. Biology of marine herbivorous fishes. Oceanogr. Mar. Biol. Ann. Rev., 27, 167-272.

Jackson, D., Williams, K.C., Degnan, B.M., 2001. Suitability of Australian formulated diets for aquaculture of the tropical abalone Haliotis asinina Linnaeus. J. Shellfish Res., 20, 627-636.

Kaehler, S., Kennish, R., 1996. Summer and winter comparisons in the nutritional value of marine macroalgae from Hong Kong. Bot. Mar., 39, 11-17.

Kunavongdate, P., Sakares, W., Muangsakorn, S., 1995. Experimental rearing on abalone, Haliotis asinina Linnaeus with three species of seaweed. Technical Paper, 39. Department of Fisheries Ministry of Agriculture and Cooperatives, Thailand.

Mabeau, S., Fleurence, J., 1993. Seaweed in food products: biochemical and nutritional aspects. Trends Food Sci. Technol., 4, 103-107.

Mai, K., Mercer, J.P., Donlon, J., 1995a. Comparative studies on the nutrition of two species of abalone, Haliotis tuberculata L. and Haliotis discus hannai Ino: III. Response of abalone to various levels of dietary lipid. Aquaculture, 134, 65-80.

Mai, K., Mercer, J.P., Donlon, J., 1995b. Comparative studies on the nutrition of two species of abalone, Haliotis tuberculata L. and Haliotis discus hannai Ino: IV. Optimum dietary protein level for growth. Aquaculture, 136, 165-180.

Mai, K., Mercer, J.P., Donlon, J., 1996. Comparative studies on the nutrition of two species pf abalone, Haliotis tuberculata L. and Haliotis discus hannai Ino: V. The role of polyunsaturated fatty acids of macroalgae in abalone nutrition. Aquaculture, 139, 77-89.

Mcbride, S.C., Rotem, E., Ben-Ezra, D., Shpigel, M., 2001. Seasonal energetics of Haliotis fulgens (Philippi) and Haliotis tuberculata (L.). J. Shellfish Res., 20, 659-665.

Mercer, J.P., Mai, K.S., Donlon, J., 1993. Comparative studies on the nutrition of two species of abalone, Haliotis tuberculata coccinea Linneaeus and Haliotis discus hannai Ino: 1. Effects of algal diets on growth and biochemical composition. Invertebr. Reprod. Dev., 23, 75-88.

Neori, A., 1996. The type of N-supply (ammonia or nitrate) determines the performance of seaweed biofilters integrated with intensive fish culture. Isr. J. Aquac.-Bamidgeh, 48, 19-27.

Neori, A., Ragg, N.L.C., Shpigel, M., 1998. The integrated culture of seaweed, abalone, fish and clams in modular intensive landbased systems: II. Performance and nitrogen partitioning within an abalone (Haliotis tuberculata) and macroalgae culture system. Aquac. Eng., 17 (4), 215-239.

Neori, A., Chopin, T., Troell, M., Buschmann, A.H., Kraemer, G.P., Halling, C., Shpigel, M., Yarish, C., 2004. Integrated aquaculture: rationale, evolution and state of the art emphasizing seaweed biofiltration in modern mariculture. Aquaculture, 231, $361-391$.

Ogino, C., Kato, N., 1964. Studies on the nutrition of abalone-II. Protein requirements for growth of abalone, Haliotis discus. Bull. Jpn. Soc. Sci. Fish., 30, 523-526 (in Japanese with English abstract).

Peña, J., 1985. Primeras experiencias de inducción a la puesta en Haliotis coccinea canariensis Nordsieck, 1975 (Grastropoda, Prosobranchia). Int. Tecn.Inst. Inv. Pesq., 130, 3-12.

Peña, J., 1986. Preliminary study on the induction of artifitial spawning in Haliotis coccinea canariensis Nordsieck (1975). Aquaculture, 52, 35-41.

Pérez, J., Moreno, E., 1991. Invertebrados Marinos de Canarias. Cabildo insular de Gran Canaria. (335 pp.).

Poore, G.C.B., 1972. Ecology of New Zealand abalones, Haliotis species (Mollusca: Gastropoda): I. Feeding. N.Z. J. Mar. Freshw. Res., 6, 11-22.

Portugal, T.R., Ladines, E.O., Ardena, S.S., Resurrección, L., Medina, C.R., Matibag, P.M., 1983. Nutritive value of some Philippine seaweeds: Part II. Proximote, amino acids and vitamin composition. Philipp. J. Nutr., 166-172.

Reyes, O.S., Fermin, A.C., 2003. Terrestrial leaf meals or freshwater aquatic fern as potential feed ingredients for farmed abalone Haliotis asinina (Linnaeus 1758). Aquac. Res., 34, 593-599.

Schuenhoff, A., Shpigel, M., Lupatsch, I., Ashkenazi, A., Msuya, F.E., Neori, A., 2003. A semi-recirculating, integrated system for the culture of fish and seaweed. Aquaculture, 221, 167-181.

Serviere-Zaragoza, E., Mazariegos-Villareal, A., Ponce-Díaz, G., Montes-Magallón, S., 2001. Growth of juvenile abalone, Haliotis fulgens Philippi, fed different diets. J. Shellfish Res., 20 (2), 689-693.

Shepherd, S.A., 1973. Studies on southern Australian abalone (Genus Haliotis): I. Ecology of five sympatric species. Aust. J. Mar. Freshw. Res., 24, 217-257.

Shepherd, S.A., Steinberg, P.D., 1992. Food preference of three Australian abalone species with the review of the 
algal food of abalone. In: Shepherd, S.A., Tegner, M.J., Guzmán del Próo, S.A. (Eds.), Abalone of the World. Biology, Fisheries and Culture. Blackwell Scientific Publications, Oxford, pp. 169-181.

Shpigel, M., Neori, A., Marshall, A., 1996a. The suitability of several introduced species of abalone (Gastropoda: Haliotidae) for land-based culture with pond-grown seaweed in Israel. Isr. J. Aquac.-Bamidgeh, 48, 192-200.

Shpigel, M., Marshall, I., Lupatsch, J.P., Mercer, J.P., Neori, A., 1996b. Acclimatation and propagation of the abalone Haliotis tuberculata in a land-based culture system in Israel. J. World Aquac. Soc., 27, 435-442.

Shpigel, M., Ragg, N.C., Lupatsch, I., Neori, A., 1999. Protein content determines the nutritional value of the seaweed Ulva lactuca for the abalone Haliotis tuberculata and H. discus hannai. J. Shellfish Res., 18, 223-227.

Smith, R.R., 1989. Nutritional energetics. In: Halver, J.E. (Ed.), Fish Nutrition, (2nd ed.)Academic Press, San Diego, CA, USA, pp. 1-29.

Steneck, R.S., Watling, L., 1982. Feeding capabilities and limitations of herbivorous mollusc: a functional group approach. Mar. Biol., 68, 299-319.

Tahil, A.S., Juinio-Menez, M.A., 1999. Natural diet, feeding periodicity and functional response to food density of the abalone, Haliotis asinina L., (Gastropoda). Aquac. Res., 30, 95-107.

Taylor, B., 1992. Abalone nutrition: optimum protein levels in artificial diets for Haliotis kamtschatkana. J. Nutr., 109, $1710-1714$.

Tenore, K., 1976. Food chain dynamics of abalone in a polyculture system. Aquaculture, 8, 23-27.

Thongrod, S., Tamtin, M., Boonyaratpalin, M., 2003. Lipid to carbohydrate ratio in donkey's ear abalone (Haliotis asinina, Linne) diets. Aquaculture, 225, 165-174.
Toledo, P., Haroun, R., Fernández-Palacios, H., Izquierdo, M., Peña, J., 2000. First culture experiences of Haliotis coccinea canariensis in a biofilter system. J. Shellfish Res., 19 (1), $493-541$.

Uki, N., Sugiura, M., Watanabe, T., 1986. Dietary value of seaweeds occurring on the Pacific coast of Tohoku for growth of the abalone Haliotis discus hannai. Bull. Jpn. Soc. Fish., 52, 257-266 (in Japanese with English abstract).

Upatham, E.S., Sawatpeeran, S., Kruatrachue, M., Chitramvong, Y.P., Singhagraiwan, T., Jarayabhand, P., 1998. Food utilization by Haliotis asinina L. J. Shellfish Res., 17, 771-776.

Viana, M.T., López, L.M., García-Esquivel, Z., Méndez, E., 1996. The use of silage from fish and abalone viscera as an ingredient for abalone feed. Aquaculture, 140, 87-98.

Viana, M.T., Jarayabhand, P., Menasveta, P., 2000. Evaluation of an artificial diet for use in the culture of the tropical abalone Haliotis ovina. J. Aquac. Trop., 15, 71-79.

Viera, M.P., Courtois de Vicose, G.B.R., Fernández-Palacios, H., Roo, J., Valencia, A., 2003. Inducción al desove de la almeja canaria Haliotis tuberculata coccinea mediante el método del peróxido de hidrogeno. Actas del IX Congreso Nacional de Acuicultura. Consejería de Agricultura y Pesca. Junta de Andalucía, pp. 289.

Wells, F.E., Keesing, J.K., 1989. Reproduction and feeding in the abalone Haliotis roei Gray. Aust. J. Mar. Freshw. Res., 40, $187-197$.

Wong, K.H., Cheung, P.C.K., 2000. Nutritional evaluation of some subtropical red and green seaweeds: Part I-proximate composition, amino acid profiles and some physico-chemical properties. Food Chem., 71, 475-482.

Zar, J.H., 1984. Biostatistical Analysis, 2nd ed. Prentice-Hall, Englewood Cliffs, New Jersey. (718 pp.). 